\title{
Recombinant Adenovirus-hIFN-beta
}

National Cancer Institute

\section{Source}

National Cancer Institute. Recombinant Adenovirus-hIFN-beta. NCI Thesaurus. Code C28550.

A recombinant replication-defective adenovirus which encodes the gene for the cytokine human interferon-beta (IFN-beta). Once inserted into and replicating in host tumor cells, recombinant adenovirus-hIFN-beta expresses human IFN-beta, which may stimulate an antiproliferative natural killer (NK) cell response against tumor cells and induce caspasemediated tumor cell apoptosis. ( $\mathrm{NCl04)}$ 